\title{
The Effect of Some New Acaricides on The Two Spotted Spider Mite Tetranychus urticae on Water Melon and Their Side Effect on Spiders ( Araneae)
}

\author{
Marguerite A. Rizk; Mona M. Ghallab; A.Y. Zaki and B. S. Wahba
}

Plant Protection Research Institute, A. R. C. Dokki, Giza, Egypt

\begin{abstract}
The efficiency of different groups of pesticides to suppress the population of the two spotted spider mite, Tetranychus urticae Koch on water melon plants was studied. The pesticides include three biochemical compounds: Yurmak 1.8\%

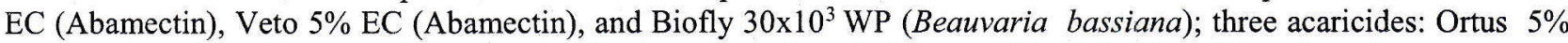
SC (Fenpyroximate), Acarots 5\% EW (Fenpyroximate) and Prince 10\% EC (Hexythiazox) and two mixture compounds: Nest 20\% SC (Abamectin 2\% + Spirodiclofen $18 \%$ ) and Perfect 12\% EW (Abamectin 2\% + Chlorfenapyr $10 \%$ ). They were applied for one time to control T. urticae infesting water melon plants during the experimental period. The different acaricides formulations were effective to control $T$. urticae for two weeks after application. Abamectin (biochemical) was more effective in reducing TSSM population than true spiders and revealed less effect on associated predators; while Hexythiazox was the most harmful acaricide in reducing true spider populations. The results will be helpful to develop IPM Programs with true spiders in agricultural crops.
\end{abstract}

Key Words: Abamectin, acaricide, Beauvaria bassiana, Chlorfenapyr, Hexythiazox Fenpyroximate, Shannon Wiener Index, Simpson Index.

\section{INTRODUCTION}

Several acaricides including flufenoxuron, fenpyroximate and abamectin are currently used in Egypt; however, the side effects of the acaricides to natural enemies are unidentified.

Many efforts have been undertaken to manage TSSM problems in agricultural crops such as the application of new acaricides with the lower concentrations to save predatory mites and true spiders. Failure of chemical control of T. urticae caused by resistance was reported in several countries for compounds such as Hexythiazox (Herron \& Rophail, 1993), Abamectin (Beers et al., 1998) and Fenpyroximate (Sato et al., 2004).

Ahn et al. (2004) found that miticides were more toxic to TSSM than to its predator, Phytoseiulus persimilis. Also, some previous studies examined the effects of some acaricides on non-target soil fauna and beneficial species such as spiders (Amalin et al. 2000; Rizk et al. 2004 \& $2005 \mathrm{Kim}$ and Yoo 2002).

In the present study, the effect of eight acaricides frequently employed in Egypt to control TSSM such as Abamectin, Fenpyroximate, Hexythiazox and Beauvaria bassiana product and their harmful effect on population density of true spiders on water melon crop were studied using topical applications and time exposure of pests. The acaricide concentration tested initially approximated field rates as recommended in 2012 by Agricultural Research Center, Ministry of Agriculture.

\section{MATERIALS AND METHODS}

\section{The study area:}

The experiment of 2012 season was conducted in Fayoum governorate. Watermelon plant was sown on $1^{\text {st }}$ June; an area of $2100 \mathrm{~m}^{2}$ was divided into 36 equal plots, each of $58 \mathrm{~m}^{2}$ that received 8 acaricides of four replicates for each treatment and control. Plots were distributed in a randomized block design. Synthetic acaricide treatments were initiated based on state recommendations. The evaluated acaricides rates and order of spray in treatments were as follow:

\begin{tabular}{|c|c|c|c|}
\hline $\begin{array}{l}\text { Trade } \\
\text { name }\end{array}$ & $\begin{array}{c}\text { Active } \\
\text { ingredient }\end{array}$ & $\begin{array}{l}\text { Rate / } \\
100 \text { L. }\end{array}$ & Type \\
\hline $\begin{array}{l}\text { Biofly } \\
30 \times 10^{3} \mathrm{WP}\end{array}$ & $\begin{array}{l}\text { Beauvaria } \\
\text { bassiana }\end{array}$ & $250 \mathrm{cc}$ & $\begin{array}{l}\text { Biochemica } \\
1\end{array}$ \\
\hline $\begin{array}{l}\text { Yurmak } \\
1.8 \% \mathrm{EC}\end{array}$ & Abamectin & $50 \mathrm{cc}$ & $\begin{array}{l}\text { Biochemica } \\
1\end{array}$ \\
\hline Veto $5 \% \mathrm{EC}$ & Abamectin & $15 \mathrm{cc}$ & $\begin{array}{l}\text { Biochemica } \\
1\end{array}$ \\
\hline $\begin{array}{l}\text { Ortus } 5 \% \\
\text { SC }\end{array}$ & Fenpyroximate & $50 \mathrm{cc}$ & Acaricide \\
\hline $\begin{array}{l}\text { Acarots } 5 \% \\
\text { EW }\end{array}$ & Fenpyroximate & $50 \mathrm{cc}$ & Acaricide \\
\hline $\begin{array}{l}\text { Prince } 10 \% \\
\text { EC }\end{array}$ & Hexythiazox & $20 \mathrm{cc}$ & Acaricide \\
\hline Nest $20 \% \mathrm{SC}$ & $\begin{array}{l}\text { Abamectin } 2 \%+ \\
\text { Spirodiclofen } 18 \%\end{array}$ & $20 \mathrm{cc}$ & Mixture \\
\hline $\begin{array}{l}\text { Perfect } 12 \% \\
\text { EW }\end{array}$ & $\begin{array}{l}\text { Abamectin2\%+ } \\
\text { Chlorfenapyr } 10 \%\end{array}$ & $30 \mathrm{cc}$ & Mixture \\
\hline
\end{tabular}

\section{Pest assessment:}

Application of the tested compounds was conducted on 11 July; pre-treatment count was recorded before spraying for each treatment. Ten 
leaves were randomly collected from each plot (replicate) and movable stages of spider mites were counted in 1 inch $^{2}$ area before spraying and after one day, 3, 7, 14 and 21 days. Percentage of reduction was calculated according to Henderson and Tilton (1955)

Percentage of reduction $=\frac{[1-\underline{\mathrm{Ta} \times \mathrm{Cb}}]}{\mathrm{Tb} \times \mathrm{Ca}} \times 100$

Where: Ta: number after treatment in treated plot.

$\mathrm{Tb}$ : number before treatment in treated plot.

$\mathrm{Ca}$ : number after treatment in check plot.

$\mathrm{Cb}$ : number before treatment in check plot.

\section{Survey of true spiders in water melon fields:}

Methods used to evaluate the side effect of this synthetic acaricides on true spider population. Samples of true spider fauna were collected weekly by pit-fall trap method as described by Southwood (1978) and Slingsby \&Cook (1986). Fourty five traps were placed in the water melon field according to the arrangement of acaricides used.

\section{Frequency and abundance values:}

The frequency values of the most abundant species were classified into three classes according to the system adopted by Weis Fogh (1948); "Constant species" more than $50 \%$ of the samples, "accessory species" $25-50 \%$ of the samples and "accidental species" less than $25 \%$. On the other hand, the classification of dominance values were done according to Weigmann (1973) system in which the species were divided into five groups based on the values of dominance in the sample; Eudominant species ( $>30 \%$ individuals), dominant species ( $>10-30 \%$ individuals), subdominant $(5-10 \%$ individuals $)$ recedent species $(1-5 \%$ individuals) and subrecedent species $(1 \%$ individuals).

\section{Species diversity:}

The biodiversity of ground spiders collected was estimated by using equilibrium. Diversity of collected spiders was determined for samples pooled over one summer season by a lot of different acaricides used to control spider mite. It was measured in each tested acaricide plots by diversity index that reflected the number of species (richness) in the samples. Two common indices were computed, Shannon-Wiener index "H" and Simpson index "S". They were calculated as described by Ludwig and Reynolds (1988). $\quad \mathrm{H}^{\prime}=-\sum(\mathrm{n} i / \mathrm{n}) \ln$ $(\mathrm{ni} / \mathrm{n})$ and $\mathrm{S}=\sum(\mathrm{n} i / \mathrm{n})^{2}$.

Where $n i$ is the number of individuals belonging to the $i^{\text {th }}$ of "S" taxa in the sample and " $n$ " is the total number of individuals in the sample. " $\mathrm{H}$ " is more sensitive to changes in number of species and diversity, while "S" is more responsive to changes in the most dominant species (Ludwig \& Reynolds, 1988).

\section{RESULTS AND DISCUSSION}

\section{The effect of tested compounds on $T$. urticae population:}

Data in Table (1) show the effect of acaricides on the two spotted spides mite populations. All the compounds tested significantly reduced spider mite popoulation on water melon plants compared with the check. Regarding the initial effect (one day after spraying), the chemical acaricide, Prince $10 \%$ EC (Hexithiazox) was more effective in controlling the spider mite mobile stages than other compounds resulting in $96.28 \%$ reduction followed by the mixture compounds, Perfect $(90.93 \%)$ and Nest $(89.12 \%)$; while the lowest reduction percentage of spider mite mobile stages recorded $50.36 \%$ and $61.46 \%$ for the acaricides, Ortus ( applied at $\left.50 \mathrm{cc} / 100 \mathrm{~L} . \mathrm{H}_{2} \mathrm{O}\right)$ and the biochemical compound Yurmak (applied at $50 \mathrm{cc} / 100 \mathrm{~L} . \mathrm{H}_{2} \mathrm{O}$ ), respectively, being insignificantly with other compounds treatments and significantly with the check.

Table (1): Effect of tested materials on Tetranychus urticae on water melon crops, 2012

\begin{tabular}{|c|c|c|c|c|c|c|c|c|c|c|}
\hline \multirow{2}{*}{ Acaricides } & \multirow{2}{*}{$\begin{array}{l}\text { No. of mites } \\
\text { pretreatment } \\
\text { / leaf }\end{array}$} & \multirow{2}{*}{$\begin{array}{l}\text { Initial effect } \\
\text { After } 1 \text { day }\end{array}$} & \multirow{2}{*}{$\mathrm{R} \%$} & \multicolumn{4}{|c|}{$\begin{array}{l}\text { No. of mites after treatment / leaf } \\
\text { (Residual effect) }\end{array}$} & \multirow[t]{2}{*}{ Total } & \multirow[t]{2}{*}{ Mean } & \multirow[t]{2}{*}{$\mathrm{R} \%$} \\
\hline & & & & 3 days & 7 days & 14 days & 21 days & & & \\
\hline Biofly & 15.6 & 2.4 & 88.84 & 2.8 & 7.6 & 8.8 & 15.6 & 34.8 & 8.7 & 85.5 \\
\hline Yurmak & 12.8 & 6.8 & 61.46 & 3.2 & 0.8 & 1.6 & 2.4 & 8.0 & 2.0 & 95.9 \\
\hline Veto & 8.0 & 2.4 & 78.24 & 3.8 & 2.4 & 2.4 & 7.2 & 15.8 & 3.95 & 87.13 \\
\hline Nest & 16.0 & 2.4 & 89.12 & 1.6 & 0.2 & 0.4 & 1.1 & 3.3 & 0.83 & 98.7 \\
\hline Perfect & 16.0 & 2.0 & 90.93 & 0.3 & 0.4 & 0.8 & 4.0 & 5.5 & 1.38 & 97.75 \\
\hline Ortus & 7.6 & 5.2 & 50.36 & 0.2 & 1.2 & 0.8 & 2.8 & 5.0 & 1.25 & 95.7 \\
\hline Acarots & 12.0 & 2.0 & 87.91 & 0.3 & 0.4 & 0.6 & 3.2 & 4.5 & 1.13 & 97.55 \\
\hline Prince & 15.6 & 0.8 & 96.28 & 1.6 & 0.8 & 10.4 & 4.8 & 17.6 & 4.4 & 92.65 \\
\hline Control & 14.8 & 20.4 & - & 22.0 & 59.2 & 62.0 & 84 & 227.2 & 56.8 & - \\
\hline
\end{tabular}

LSD at $5 \%=8.2$ 
Table (2): Effect of different acaricides on spiders collected by pitfall trap under water-melon plants at Fayoum.

\begin{tabular}{|c|c|c|c|c|c|c|c|c|c|c|c|c|c|c|c|c|c|c|c|c|c|c|c|c|}
\hline \multirow{2}{*}{$\begin{array}{l}\text { Families \& } \\
\text { taxa names }\end{array}$} & \multicolumn{3}{|c|}{ Biofly } & \multicolumn{3}{|c|}{ Yurmac } & \multicolumn{3}{|c|}{ Veto } & \multicolumn{3}{|c|}{ Nest } & \multicolumn{3}{|c|}{ Perfect } & \multicolumn{3}{|c|}{ Ortus } & \multicolumn{3}{|c|}{ Acarots } & \multicolumn{3}{|c|}{ Prince } \\
\hline & $\delta$ & 웅 & $\mathrm{J}$ & $\hat{0}$ & 오 & $\mathrm{J}$ & $\hat{0}$ & 오 & $\mathrm{J}$ & $0^{\pi}$ & $q$ & $\mathrm{~J}$ & $\hat{0}$ & 9 & $\mathrm{~J}$ & $0^{-1}$ & 9 & $\mathrm{~J}$ & 8 & 오 & $\mathrm{J}$ & $0^{\pi}$ & 9 & $\mathrm{~J}$ \\
\hline \multicolumn{25}{|l|}{ Lycosidae } \\
\hline Wadicosa fidelis & 13 & 5 & 6 & 8 & 3 & 15 & 10 & 7 & - & 13 & 3 & 1 & 9 & 3 & 3 & 12 & 4 & 25 & 13 & 2 & 4 & 3 & 1 & 3 \\
\hline Pardosa spl & 2 & & 2 & & 1 & 3 & 2 & 1 & 30 & 1 & - & - & 4 & - & 1 & 1 & - & - & 2 & 1 & & 1 & - & - \\
\hline Pardosa sp2 & 6 & 1 & - & 4 & 1 & 1 & & 1 & - & 2 & - & 2 & - & 1 & 13 & 2 & - & - & 1 & - & 1 & 2 & - & - \\
\hline Hogna ferox & 1 & & - & 1 & 1 & & 2 & 2 & - & 3 & 1 & 52 & - & - & - & - & - & - & 1 & - & - & - & - & - \\
\hline \multicolumn{25}{|l|}{ Philodromidae } \\
\hline Philodromius sp. & 6 & - & 1 & 1 & - & 1 & 2 & - & - & 2 & - & 3 & 1 & - & 2 & 3 & 1 & - & 2 & 1 & 1 & 2 & - & - \\
\hline Linyphidae & & & 1 & & & & 1 & & & & & & & & & & & & & & & & & \\
\hline Prinerigone vagans & - & - & - & & - & - & - & - & - & - & - & - & - & - & - & $\cdots$ & - & - & - & - & - & - & - & - \\
\hline \multicolumn{25}{|l|}{ Miturgidae } \\
\hline Cheiracanthium sp. & - & 1 & - & & - & - & - & - & - & - & - & - & - & - & - & - & - & - & - & - & - & - & - & - \\
\hline \multicolumn{25}{|l|}{ Gnaphosidae } \\
\hline Zelotes sp. & 2 & 1 & - & & 2 & - & 1 & - & - & 1 & - & - & 1 & - & - & $\because$ & - & - & - & - & - & - & - & - \\
\hline Salticidae & & & & & & & & & 1 & & & & & & & & & & & & & & & \\
\hline Phlegra fla & - & - & - & & - & - & - & - & - & 2 & - & - & 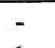 & $=$ & - & 1 & - & - & 2 & - & - & 1 & - & - \\
\hline Pellenes sp. & - & - & - & & - & - & - & - & - & - & - & - & 1 & - & - & - & - & - & & - & - & - & - & \\
\hline Thomisidae & & - & & & & & & & & & & & & & & & & & & & & & & \\
\hline Thomisus spinifer & - & - & - & & - & - & - & - & - & - & - & - & - & - & - & 1 & - & - & - & - & - & - & - & 1 \\
\hline Theridiidae & & & & & & & & & & & & & & & - & & & & & 1 & 1 & & & \\
\hline Steatoda erigoniformis & - & - & - & 2 & - & - & - & - & 1 & 1 & - & 1 & - & - & - & - & - & - & - & - & - & - & - & - \\
\hline Total & 30 & 8 & 10 & 16 & 8 & 20 & 18 & 11 & 32 & 25 & 4 & 59 & 16 & 4 & 19 & 20 & 5 & 25 & 21 & 5 & 7 & 9 & 1 & 4 \\
\hline Grand Total & & 48 & & & 44 & & & 61 & & & 88 & & & 39 & & & 50 & & & 33 & & & 14 & \\
\hline
\end{tabular}

Table (3): The dominance-frequency relationship of spider communities (2012)

\begin{tabular}{|c|c|c|c|c|c|c|c|c|c|c|c|c|c|c|c|c|}
\hline \multirow[t]{2}{*}{ Fam. } & \multicolumn{4}{|c|}{ Biofly } & \multicolumn{4}{|c|}{ Yurmac } & \multicolumn{4}{|c|}{ Veto } & \multicolumn{4}{|c|}{ Nest } \\
\hline & Total & F. $\%$ & Freq. & Dom. & Total & F.\% & Freq. & Dom. & Total & F.\% & Freq & Dom. & Total & F.\% & Freq & Dom. \\
\hline A & 36 & 75 & $\mathrm{C}$ & $\mathrm{E}$ & 38 & 86.3 & C & $\mathrm{E}$ & 55 & 90.2 & $\mathrm{C}$ & E & 78 & 88.6 & $\mathrm{C}$ & $E$ \\
\hline B & 7 & 14.6 & A & $\mathrm{D}$ & 2 & 4.5 & $\mathrm{~A}$ & $\mathrm{R}$ & 2 & 3.3 & A & $\mathrm{R}$ & 5 & 5.7 & $\mathrm{~A}$ & $\mathrm{Sd}$ \\
\hline$\cdot \mathrm{C}$ & 1 & 2.1 & $\mathrm{~A}$ & $\mathrm{R}$ & - & - &  & - & 1 & 1.6 & $\mathrm{~A}$ & $\mathrm{R}$ & - & - & - & - \\
\hline D & 1 & 2.1 & A & $\mathrm{R}$ & - & - & - & - & - & - & - & - & - & - & - & - \\
\hline$E$ & 3 & 6.3 & A & $\mathrm{Sd}$ & 2 & 4.5 & A & $\mathrm{R}$ & 1 & 1.6 & $\mathrm{~A}$ & $\mathrm{R}$ & 1 & 1.1 & A & $\bar{R}$ \\
\hline$F$ & - & - & - & - & - & - & - & - & 1 & 1.6 & $\mathrm{~A}$ & $\mathrm{R}$ & 2 & 2.3 & $\mathrm{~A}$ & $\mathrm{R}$ \\
\hline $\mathrm{G}$ & - & - & - & - & - & - & - & - & - & - & - & - & - & - & - & - \\
\hline $\mathrm{H}$ & - & - & - & - & 2 & 4.5 & A & - & 1 & 1.6 & $\mathrm{~A}$ & $\mathrm{R}$ & 2 & 2.3 & $\mathrm{~A}$ & $R$ \\
\hline Total & \multicolumn{4}{|c|}{48} & \multicolumn{4}{|c|}{44} & \multicolumn{4}{|c|}{61} & \multicolumn{4}{|c|}{88} \\
\hline \multirow[t]{2}{*}{ Fam. } & \multicolumn{4}{|c|}{ Perfect } & \multicolumn{4}{|c|}{ Ortus } & \multicolumn{4}{|c|}{ Acarots } & \multicolumn{4}{|c|}{ Prince } \\
\hline & Total & F.\% & Freq. & Dom. & Total & F.\% & Freq. & Dom. & Total & F.\% & Freq & Dom. & Total & F. $\%$ & Freq & Dom \\
\hline $\bar{A}$ & 34 & 87.2 & $\mathrm{C}$ & $\mathrm{E}$ & 44 & 88 & C & $E$ & 25 & 75.8 & C & $E$ & 10 & 71.4 & $\mathrm{C}$ & $E$ \\
\hline B & 3 & 7.7 & $\mathrm{~A}$ & $\mathrm{Sd}$ & 4 & 8 & $\mathrm{~A}$ & $\mathrm{Sd}$ & - & 12.1 & $\mathrm{~A}$ & D & 2 & 14.3 & $\mathrm{~A}$ & $\mathrm{D}$ \\
\hline C & - & - & - & - & - & - & - & - & - & - & - & - & - & - & - & - \\
\hline $\mathrm{D}$ & - & - & - & - & - & - & - & - & - & - & - & - & - & - & - & - \\
\hline E & 1 & 2.6 & A & $\mathrm{R}$ & - & - & - & - & - & - & - & - & - & - & - & - \\
\hline$F$ & - & 2.6 & $\mathrm{~A}$ & $\mathrm{R}$ & 1 & 2 & A & $\mathrm{R}$ & 2 & 6.1 & $\mathrm{~A}$ & $\mathrm{Sd}$ & 1 & 7.1 & A & $\mathrm{Sd}$ \\
\hline $\mathrm{G}$ & - & - & - & - & 1 & - & A & $\mathrm{R}$ & - & - & - & - & 1 & 7.1 & $\mathrm{~A}$ & $\mathrm{Sd}$ \\
\hline $\mathrm{H}$ & - & - & - & - & - & - & - & - & 2 & 6.1 & A & $\mathrm{Sd}$ & - & - & - & - \\
\hline Total & & & 39 & & & & 50 & & & & 33 & & & & 14 & \\
\hline
\end{tabular}

A : Lycosidae ; B : Philodromidae ; C : Linyphiidae; D: Miturgidae; E : Gnaphosidae

F : Salticidae; G : T'lomisidae; H : Theridiidae

Frequency (abundance), by Weis Fog

$>50 \%=$ Constant $(\mathrm{C}) ; 25-50 \%=$ Accessory $($ ac $) ;>25 \%=\operatorname{Accidental}(\mathrm{A})$

Dominance, by Weigmann

$>30 \%=$ Eudominant $(\mathrm{E}) ; \quad 10-30 \%=$ Dominant $(\mathrm{D}) ; \quad 5-10 \%=$ Subdominant $(\mathrm{sd})$

$1-5 \%$ Recedent $(\mathrm{R}) ;>1 \%=$ Subrecedent $(\mathrm{Sr})$ 
After 3, 7, 14 and 21 days of spray, the reduction percentages of spider mite increased with the time elapsed after treatment. All the tested compounds significantly reduced the spider mite compared with the population check except of plot treated with Biofly, the efficacy of the compound decreased from $88.84 \%$ to $85.5 \%$ which indicate that Biofly caused spider mite populations rebounds; this may be due to some abiotic factors.

Moreover, the mean counts of reduction percentage of the tested compounds throughout 3,7 , 14 and 21 days recorded that both mixture compounds Nest 20\% SC (Abamectin 2\% + Spirodiclofen $18 \%$ ) and Perfect $12 \%$ EW (Abamectin 2\% + Chlorfenapyr 10\%) showed the highest reduction 98.7 and $97.75 \%$, respectively, compared to other compound treatments; followed by the acaricide Acarots ( $97.55 \%$ ) being significantly with untreated check and insignificant with other compounds. While the biochemical compounds Biofly and Veto gave the lowest mean percentage of reduction (85.5 and $87.13 \%$ ), respectively, being significantly with untreated check and insignificant with other compounds.

\section{Spider assemblages:}

As shown in Table (2), a total number of 377 spiders were collected during this experiment; belonged to 8 families, 11 genera and 12 species. Juvenile comprised $46.7 \%$; while males and females were $53.3 \%$. The sex ratio was 1 ㅇ: $3.4 \delta$.

The highest percent of their occurrence was presented by Wadicosa fidelis Octavius (166 individuals), Hogna ferox Lucas (64), Pardosa $s p_{1}$ (52) and Pardosa $s p_{2}$ (38) all of family Lycosidae. Rizk et al. (2004) indicated that spiders of family Lycosidae are more frequent in pitfall traps and showing a certain degree of resistance to acaricides. Family Salticidae was represented by 2 genera (Phlegra flavipes Denis \& Pellenes sp.). Members of the remaining families Philodromidae (Philodromus sp) Miturgidae ( Cheiracanthium sp.), Linyphidae (Prinerigone vagans Savigny), Gnaphosidae (Zelote sp. ), Thomisidae (Thomisus spinifer O.P.) and Theridiidae ( Steatoda erigoniformis O.P.) were noted in few numbers by only a single species for each.

\section{Effect of tested compounds on spiders associated with $T$. urticae:}

Different compounds influenced spider abundance. The effect of tested compounds against predators (spiders) associated with the red spider mite T. urticae is presented in Table (2). Results showed that the acaricides Prince (Hexythiazox ) and Acarots $5 \% \mathrm{E} \mathrm{W}$ (fenpyroximate) were the most effective pesticides on predators, whereas the total numbers of collected spiders were lower than other tested compounds recording 14 and 33 individuals, respectively. The results are in harmony with results reported for fenpyroximate by Abd-Elhady et al. (2011). They reported that the use of this compound in the field would probably result in severe reduction of the predator, $P$. persimilis; while the lowest numbers in male, female and juvenile of the spiders found in plot treated with Prince, recorded 14 individuals belonged to 6 species and 4 families. John (1988) studied the toxicity of hexythiazox to mite eggs and their larval stage and registred the microscopic examination of eggs treated with lethal dose of Hexythiazox showed that embryos reach an advanced stage of development before dying. Rizk et al. (2004) cited the dangerous of acaricides use on the biodiversity of the true spider fauna.

The highest numbers of individuals (88) was recorded in the plot treated with Nest (Abamectin + Spirodiclofen ) decreased to 39 individuals in plot treated with Perfect(Abamectin + Chlorfenapyr). These results agreed with Maeyer et al. (2002) who proved that Spirodiclofen provided excellent control to Lepidosaphes ulmi L. and showed no adverse effect on natural predators of pear Psylla (Anthocoridae). While the higher dose of chlorfenapyr (125 g /ha) was at par in reducing the predatory population level to the tune of 31.13 as proved by Sarkar and Samanta (2010) and also they concluded that, chlorfenapyr at $75 \mathrm{~g} /$ ha was safe for the natural enemies in chilli eco-system. In this respect, it is recorded that Nest had the lowest toxic effect against predators associated with the red spider mite $T$. urticae and was the most toxic pesticide against the red spider mite.

The microbial pesticides Biofly and Veto showed intermediate reduction percentage of predator's population. This result is in agreement with the findings of Sabra et al. (2005) who indicate that Biovar was moderately effective against Thrips but less effective against associated predators. Moreover, Gillespie, A.T. (1986) proved that Thrips tabaci susceptible to Beauvaria bassiana which killed all treated insects within 4 days.

Plots treated with the biochemical compounds, the Veto (Abamectin $15 \mathrm{cc}$ ) received 61 individuals decreased to 44 individuals in plot treated with 
Table (4): Estimation of Shannon-Wiener and Simpson Indices of diversity in different cover cultivations

\begin{tabular}{lcccccccc}
\hline \multicolumn{1}{c}{ Type of index } & Biofly & Yurmak & Veto & Nest & Perfect & Ortus & Acarots & Prince \\
\hline Shannon-Wiener Index & 0.83 & 0.55 & 0.47 & 0.4 & 0.5 & 0.46 & 0.80 & 0.89 \\
Simpson Index & 0.59 & 0.75 & 0.82 & 0.79 & 0.77 & 0.78 & 0.59 & 0.5 \\
\hline
\end{tabular}

Yurmak (Abamectin $50 \mathrm{cc}$ ); Miranda et al. (2005) found that the predators, Anthicus sp., Orius sp., Xylocopa sp., and Straphillinid populations were severely reduced by excessive pesticides, Abamectin and Chlorothalonil applications in water plant plantations.

In general, the chemical compounds Prince and Acarots revealed high toxic effects against the two spotted spider mite, T. urticae and reduced spider population; while the mixture compound Nest, the biochemical Veto and the acaricide Ortus showed the highest total number of individuals of 88,61 , and 50 individuals, respectively with less effective against associated predators.

\section{Frequency and abundance values:}

Table (3) showed the frequency and abundance values of the most abundant spiders. Family Lycosidae was considered constant according to the system adopted by Weis Fogh (1948) under different application in all plots and it recorded 75, 86.3, $90.2,88.6,87.2,88,75.8, \& 71.4 \%$ in plots treated with Biofly, Yurmak, Veto, Nest, Perfect, Ortus, Acarots and Prince, respectively. Wadicosa fidelis Octavius was the most common member recorded Eudominant in all treatments except of plots treated with Veto and Nest recorded dominant. Families Philodromidae, Linyphidae, Miturgidae, Gnaphosidae, Salticidae, Thomisidae and Theridiidae were considered Accidental families under different applications in all plots.

This result agreed with Rizk et al. (2012) who indicated that members of Lycosidae were represented by three most common species, Wadicosa fidelis Octavius, Pardosa injucanda and Pardosa sp. and all their developmental structure were collected by pitfall traps below the four examined plants(the spearmint, castor bean, roselle and red pepper ). Also, Shuang-lin, J. and Bo-ping L.(2006) indicated that Lycosidae was dominant families and occupied more than $60 \%$ of individual community.

\section{Species diversity:}

The biodiversity of spiders in the eight plots treated by different acaricides is compared using Shannon Wiener "H"' and Simpson "S" Indices of diversity (Table 4). The cover plantation of water melon in different plots varies in their species richness; the plot treated with Nest recorded the highest population of total number 88 individuals (Table 2). Its ecosystem is made of 5 families, 7 genera and 8 species; followed by Veto recorded spider population of 61 individuals, belonging to 6 families, 8 genera and 8 species. While the plot treated by the acaricide, Prince and Acarots recorded the least species richness of 14 and 33 individuals, respectively.

The biodiversity index calculation indicates that Biofly, Acarots and Prince were the most diverse; the species richness of spiders in different families and their equitability (evenness) were higher.

According to Simpson Index which is a measure of dominance (responsive to changes for the most dominant species), it was found that Veto and Nest included the highest number of dominant species of values 0.82 and 0.79 , respectively.

The relative toxicity of pesticides to pests, predators and immature stages of the predators should provide an adequate indicator for selectivity of pesticides, which is essential for development of pest management programs (Jeppson et al. 1975).

Results showed that treatments of acaricides revealed a higher rate of $T$. urticae mortality compared with non treated plot and also affect the activity density of spider. $T$. urticae numbers on plots treated with acaricides were significantly lower than plots treated with Biof? $y$ and Control.

Among the acaricides evaluated, Prince (Hexythiazox ) was harmless to true spiders; Nadimi et al. (2008) indicated this result with P. persimilis; while the two products of Fenpyroximate (Acarots and Ortus ) gave different effect on spider, Acarots was more harmful to spider than Ortus. The present results are consistent with that reported by (Blumel \& Hausdrof, 2002) and Nadimi et al. (2008).

Also, spider has responded differently to the two products of Abamectin. Results obtained reveal the reduction of true spiders in plots treated with Yurmak more than that obtained from Veto. Also, the compound Nest (Abamectin + Spirodiclofen $18 \%$ ) was harmless to true spiders and might cause 
hatching of eggs which result in increase the total number of individuals. This result confirmed by Nadimi et al. (2008) which proved that Abamectin was moderately harmful to spider.

As Abamectin, Fenpyroximate and Biofly are very effective they should be used carefully and may be classified as IPM compatible acaricide in integrated pest management programs against $T$. urticae in Egypt.

\section{REFERENCES}

Abd-Elhady, H.K. and Heikal, H.M.M. 2011. Selective toxicity of three acaricides to the twospotted spider mite Tetranychus urticae and predatory Mite Phytoseuilus persimilis in apple orchards. Journal of Entomology, 8: 574-580.

Ahn, K.; Lee, S.Y.; Lee, K. Y.; LEE, Y. S. and Kim, G.H. 2004. Selective toxicity of pesticides to the predatory mite, Phytoseiulus persimilis and control effects of the two spotted spider mite, Tetranychus urticae by predatory mite and pesticide mixture on rose. Korean. Appl. Entomol., 43: 71 -79.

Amalin, D.M.; Pena, J.; Yu, S.J. and Sorley, R. Mc. 2000. Selective toxicity of some pesticides to Hibana Velox (Araneae: Anyphaenidae)a predator of citrus leafminer. Florida Ent., 83: $254-261$

Beers, E.H.; Riedl, H. and Dunley, J.E. 1998. Resistance to a amectin and reservation to susceptibility to Fenbutation oxide in spider mite (Acari: Tetranychidae) population in Pacific North West. J. Eco. Entom., 91: 352- 360.

Blumel, S. and Hansdorf, H. 2000. Results of $8^{\text {th }}$ and $9^{\text {th }}$ IOBC joint pesticides testing programmed: persistence test with Phytoseiulus persimilis Athias-Henriot (Acari: Phytoseiidae) IOBC/ Wprs, 25: 43-51.

Gillespie, A.T. 1986. The potential of entomogenous fungi as control agents for onion thrips. Thrips tabaci Monograph , British Crop Protection Council, 34: $237-243$.

Herron, G. A. and Rophail, J. 1993. Clofentezin and - Hexythiazox resistance in Tetranychus urticae Koch in Australia. Experimental and Applied Acarology, 17: 433 - 440.

Jeppson, L.R., Mcmurtry, J.A.; Mead, D.W.; Jesser, M.J. and Johnson, H.G. 1975. Toxicity of citrus pesticides to some predacious phytoseiid mites. J. Econ. Entomol., 68: 707-710.

John-Marris, W. M. 1988. The toxicity of hexythiazox to two spotted spider mite (Tetranychus urticae Koch) adults and eggs,
Master of Applied Science, 73 pp University of Canterbury.

Kim, S. S. and Yoo, S. S. 2002.Comparative toxicity of some acaricides to the predatory mite Phytoseiulus persimilis and the two spotted spider mite_Tetranychus urticae. Biocontrol, 47: $563-573$.

Ludwig, J.A. and Reynolds, J.F. 1988. Statistical Ecology: A primary methods and computing New-York 337pp.

Maeyer, L. de; Peeters, D.; Wijsmuller, J. M.; Cantoni, A.; Brueck, E. and Heibges, S. 2002 Spirodiclofen: a broad-spectrum acaricide with insecticidal properties: efficacy on Psylla pyri and scales Lepidosaphes ulmi and Quadraspidiotus perniciosus. The BCPC Conference: Pests and diseases, Volumes 1 \& 2. Proceedings of an international conference, Brighton, UK, 18-21 November 2002: p. 65-72.

Nadimi, A. ; Kamali, K.; Arbabi, M. and Fateme, A. 2008. Side effect of three acaricides on the predatory mite Phytoseiulus persimilis under laboratory condition. Mun. Ent. Zool., (3): 556 567

Rizk, M. A. ; Iskander, A. K.F. ; Habashi, N. H. and Ghallab, M.M. 2004. The effect of some new miticides on spider mites (Tetranychus

urticae) and their side effect on true spiders in cucumber crops in Fayoum, Egypt. J. Agricult. Sc. Of Mansoura Univ., 29 (7): 4245 - 4251.

Rizk, M. A.; Ghallab, M.M.; Habashi, N. H. and Allam, S.A. 2005. The effect of acaricides treatment on some nen target soil fauna in cucumber crops at Fayoum governorate, Egypt. Egypt. J. Agric. Res., 83(1): $293-300$.

Rizk, M. A.; Sallam, G.M.E.; Abdel-Azeem, N.A. and Ghallab, M.M. 2012. Spider occurrence in fields of some medicinal and ornamental plants in Fayoum. Acarines, 6: $41-47$.

Sabra, I. M.M.; El-Nagar, M. A. and Khewa, M.M.I 2005. Efficacy of some non-chemical insecticides against Thrips tabaci Lind. and its associated predators. Egypt. J. Agric. Res. Special issue, $3^{\text {rd }}$ Internat. Conf. of PPRI, $26-29$ Nov. 2005: 653 -659 .

Sato, M. F.; Miyata, T.; Silva, M. and Souza-Filho, M. F. 2004. Selection for Fenpyroximate resistance and susceptibility and inheritance, Cross resistance and stability of Fenpyroximate resistance in Tetranychus urticae (Acari: Tetranychidae). Appl. entom. and Zool., 39: 293-302.

Sarkar, P. K. and Samanta, S. K. 2010. Sustainable management of Chilli yellow thrips (Scirtothrips Dorsalis Hood) and Chilli broad mite 
(Polyphagotarsonemus Latus Banks) in India. https://www.google.com.eg

Slingsby, D. and Cook, C. 1986. Practical Ecology. Macmillan, London: $213 \mathrm{pp}$.

Southwood, T.R.E. 1978. Ecological methods with particular reference to the study of insect population. Chapman and Hall, London: 524 pp.
Weigmann, G. 1973. Zur Okologie der collemolen and Oribatiden in Gerenzhereich Land-Meer (Collembola, Insects Oribatei, Acari). Z. iwss. Zool, Leipzig, 186 (3/4): 295.

Weis Fogh, T. 1948. Ecological investigation on mites. and collembolan in the soil. Nat. Jutlant., 1: $135-270$. 